\title{
Assessment of biochar and zero-valent iron for in-situ remediation of chromated copper arsenate contaminated soil
}

Frick, Hanna; Tardif, Stacie; Kandeler, Ellen; Holm, Peter E.; Brandt, Kristian K.

Published in:

Science of the Total Environment

DOI:

10.1016/j.scitotenv.2018.11.193

Publication date:

2019

Document version

Peer reviewed version

Document license:

CC BY-NC-ND

Citation for published version (APA):

Frick, H., Tardif, S., Kandeler, E., Holm, P. E., \& Brandt, K. K. (2019). Assessment of biochar and zero-valent iron for in-situ remediation of chromated copper arsenate contaminated soil. Science of the Total Environment, 655, 414-422. https://doi.org/10.1016/j.scitotenv.2018.11.193 


\section{Assessment of biochar and zero-valent iron for in-situ remediation of chromated copper arsenate contaminated soil}

Hanna Frick ${ }^{a, b, c}$, Stacie Tardifa, Ellen Kandeler ${ }^{b}$, Peter E. Holm ${ }^{a}$, Kristian K. Brandt ${ }^{a^{*}}$

a Department of Plant and Environmental Sciences, University of Copenhagen, Thorvaldsensvej 40, DK-1871Frederiksberg C, Denmark, kkb@plen.ku.dk

b Institute of Soil Science and Land Evaluation, Soil Biology Department, University of Hohenheim, Emil-Wolff-Str. 27, 70599 Stuttgart, Germany

c Department of Soil Science, Research Institute of Organic Agriculture FiBL, Ackerstrasse 113, 5070 Frick, Switzerland

${ }^{*}$ Corresponding author 
Highlights

- Chromate copper arsenate (CCA) contaminated soils pose risks to the environment

- In-situ stabilization of CCA contaminated soil was tested with biochar and ZVI

- Soil remediation was evaluated based on chemical and microbiological techniques

- Biochar reduced bioavailable ( $\left.\mathrm{Cu}_{\text {bio }}\right)$, but not water-extractable $\mathrm{Cu}\left(\mathrm{Cu}_{\text {water }}\right)$

- Combination of biochar and ZVI most effectively reduced toxic effects of CCA 


\section{Abstract}

2 Chromated copper arsenates (CCA) have been extensively used as wood impregnation agents in

3 Europe and North America. Today, CCA contaminated sites remain abundant and pose environmental

4 risks that need to be properly managed. Using a TRIAD approach that combined chemical,

5 ecotoxicological and ecological assessment of soil quality, we investigated the abilities of biochar and

6 zero-valent iron (ZVI) to remediate CCA contaminated soil in a microcosm experiment. Soil samples

7 from a highly contaminated CCA site (1364, 1662 and $540 \mathrm{\mu g} \mathrm{g}^{-1}$ of As, $\mathrm{Cu}$ and $\mathrm{Cr}$, respectively) were

8 treated with two different biochars (fine and coarse particle size; $\left.1 \% \mathrm{w} \mathrm{w}^{-1}\right)$ and ZVI $\left(5 \% \mathrm{w} \mathrm{w}^{-1}\right)$, both

9 as sole and as combined treatments, and incubated for 56 days at $15{ }^{\circ} \mathrm{C}$. In general, bioavailable As

$\left(\mathrm{As} \mathrm{s}_{\text {bio }}\right)$ and $\mathrm{Cu}\left(\mathrm{Cu}_{\text {bio }}\right)$ determined by whole-cell bacterial bioreporters corresponded well to water-

extractable As and $\mathrm{Cu}\left(\mathrm{As}_{\text {water }}\right.$ and $\left.\mathrm{Cu}_{\text {water }}\right)$. However, in biochar treatments, only $\mathrm{Cu}_{\text {bio }}$ and not $\mathrm{Cu}_{\text {water }}$

was significantly reduced. In contrast, under ZVI treatments only $\mathrm{Cu}_{\text {water }}$ and not $\mathrm{Cu}_{\text {bio }}$ was reduced,

demonstrating the value of complementing analytical with bacterial bioreporter measurements to infer bioavailability of elements to soil microorganisms. The combined fine particle size biochar and ZVI treatment effectively reduced water extractable concentrations of $\mathrm{Cr}, \mathrm{Cu}$, and As on site by $45 \%$, $45 \%$ and $43 \%$ respectively, and led to the highest ecological recovery of the soil bacterial community, as measured using the $\left[{ }^{3} \mathrm{H}\right]$ leucine incorporation technique. We conclude that the combined application of biochar and ZVI as soil amendments holds promise for in-situ stabilization of CCA contaminated sites.

\section{Keywords}


Chromated copper arsenate (CCA) constitutes a mixture of $\mathrm{Cr}$ and $\mathrm{Cu}$ salts $\left(\mathrm{CrO}_{3}\right.$ and $\left.\mathrm{CuO}\right)$ and arsenic $\operatorname{acid}\left(\mathrm{H}_{3} \mathrm{AsO}_{4}\right)$ and has been extensively used as a wood preservative since the $1940 \mathrm{~s}$. In 2003, legislation in Europe and North America was passed which severely limited CCA application (European Commission, 2003; Humphrey, 2002; U.S. EPA, 2002), but a large number of CCA legacy contaminated sites remain (Bhattacharya et al., 2002; Hopp et al., 2006), with more than 100 sites in Denmark alone (Amternes Videncenter for Jordforurening, 1997; Nielsen et al., 2010).

CCA contaminated sites are of environmental concern as $\mathrm{Cr}$, $\mathrm{Cu}$ and As pose severe risks to both human and environmental health. Arsenic is of particular concern due to its toxicity and mobility, by which it may also threaten surface and groundwater drinking water resources (Nielsen, 2013). In soils, As occurs most commonly as the inorganic oxyanions arsenite $(\mathrm{As}(\mathrm{III}))$ and arsenate $\mathrm{As}(\mathrm{V}))$ (Masscheleyn et al., 1991), with As(III) generally the most toxic and mobile form (Peters et al., 1996). However, Cu is less mobile, but may adversely affect ecosystem services provided by soil biota (Arthur et al., 2012; Nunes et al., 2016) and co-select for antibiotic resistance (Ashbolt et al., 2013; Song et al., 2017). Cr occurs in soil mostly as $\mathrm{Cr}(0), \mathrm{Cr}(\mathrm{II}), \mathrm{Cr}(\mathrm{III})$ and $\mathrm{Cr}(\mathrm{VI})$, with $\mathrm{Cr}(\mathrm{III})$ the most stable and prevalent $\mathrm{Cr}$ redox species in most soils (Namiesnik and Rabajczyk, 2012), but the $\mathrm{Cr}(\mathrm{VI})$ species used in CCA formulations is considered substantially more toxic than reduced forms of $\mathrm{Cr}$ (Nielsen et al., 2010).

CCA and other multi-element contaminated soils can be remediated in various ways. Full remediation is often only possible by excavation, but due to the sheer number and size of contaminated sites worldwide, this approach is seldom feasible (Nielsen et al., 2016). Hence, insitu stabilization by application of different soil amendments has been proposed as a more economical approach for reducing the mobility and toxicity of trace element contaminants (Bolan et al., 2014; Maurice et al., 2007), but the challenge remains to identify suitable soil amendments for 
multi-element contaminated sites, as the individual elements may respond differently to soil treatments (Kumpiene et al., 2008; Qiao et al., 2018; Silvetti et al., 2014; Zhou and Haynes, 2010).

Biochar, a solid produced by pyrolysis of organic material, has gained particular interest as a cheap and effective amendment for remediation of cationic pollutants such as $\mathrm{Cu}$, mainly by increasing $\mathrm{pH}$ and providing additional sorption sites (Beesley et al., 2011; Buss et al., 2012; Ippolito et al., 2012; Lehmann and Joseph, 2015). However, biochar may not work equally well for anionic trace element contaminants, as previous studies have observed an increase in bioavailability and mobility of As (Beesley et al., 2010; Hartley et al., 2009; Kim et al., 2018; Wang et al., 2017). Rather, iron-bearing compounds such as zero-valent iron (ZVI) have proven more useful for in-situ stabilization of As (Kumpiene et al., 2006; Miretzky and Cirelli, 2010; Nielsen et al., 2011). Sneath et al. (2013) proposed a combination of biochar and ZVI as a promising amendment for in situ stabilization of soil contaminated with complex mixtures of metals, arsenic and organics. Several recent studies investigated the synthesis and characterization of iron-coated biochar for metal(loid) removal from aqueous media and found enhanced sorption of $\mathrm{Cr}(\mathrm{VI})$ (e.g. Zhu et al., 2018; B. Wu et al., 2018; Diao et al., 2018), Cu (e.g. Kolodynska and Bak, 2018; Yang et al., 2018b) as well as As (e.g. Bakshi et al., 2018; He et al., 2018; Zhou et al., 2014). However, the combination of biochar and iron as a treatment for remediation of multi-element contamination of soils and other media is less well studied (Lu et al., 2018).

Consequently, the aim of the present study was to perform a soil microcosm study to understand both the independent and combined efficiency of biochar and ZVI for stabilizing CCA contaminated soil. Remediation treatment effects were assessed after 1, 7, 28 and 56 days using a soil quality TRIAD approach. The TRIAD approach combines investigations of soil chemistry (exposure and bioavailability), (eco)toxicology, and ecology as recently recommended for site-specific risk assessment of contaminated soils (ISO 19204, 2017). Exposure and bioavailability were assessed by a combination of chemical analyses (ICP-OES, trace element speciation analysis etc.) and of bioluminescent whole- 
cell bacterial bioreporters responding specifically to bioavailable $\mathrm{Cu}$ and $\mathrm{As}$, respectively. Soil toxicity was assessed in a laboratory bioluminescence inhibition assay with a whole-cell bacterial bioreporter. Soil ecology was studied by following the recovery of growth in indigenous soil bacteria as measured by the $\left[{ }^{3} \mathrm{H}\right]$ leucine incorporation technique, providing a proxy for secondary bacterial productivity (Brandt et al., 2015). We hypothesized that a combination of ZVI and biochar would be more efficient in reducing environmental risks posed by $\mathrm{Cr}$, $\mathrm{Cu}$ and $\mathrm{As}$ in $\mathrm{CCA}$ contaminated soil than independent applications of ZVI and biochar. In addition, we hypothesized that the high surface area of fine biochar would stabilize multiple elements more efficiently than coarse biochar.

\subsection{CCA contaminated soil and experimental soil amendments}

Contaminated soil was collected from the upper $20 \mathrm{~cm}$ of a former wood impregnation site north of Copenhagen, Denmark (sampling point: $55^{\circ} 57^{\prime} 19.7^{\prime \prime} \mathrm{N} 12^{\circ} 21^{\prime} 18.1^{\prime \prime} \mathrm{E}$, station L4), highly contaminated with $\mathrm{Cr}$, $\mathrm{Cu}$, and As (see Nielsen et al., 2011, for detailed site description and Tardif et al., 2019, for detailed physico-chemical characterization). The texture was classified as loamy sand with $39.9 \%$ coarse sand $(200-2000 \mu \mathrm{m}), 44.6 \%$ fine sand $(20-200 \mu \mathrm{m}), 11.0 \%$ silt $(2-20 \mu \mathrm{m})$, and $4.5 \%$ clay $(<2$ $\mu \mathrm{m})$ and had an initial gravimetric moisture content of $17.0 \%$. After sampling, soil was placed under a fume hood for air-drying, sieved ( $2 \mathrm{~mm}$ mesh) and stored in plastic buckets until setup of soil microcosm experiments. General soil characteristics are summarized in Table 1.

Biochar in two different particle sizes was produced from Miscanthus $x$ giganteus (charring at $850^{\circ} \mathrm{C}$ for $30 \mathrm{~min}$; PYREG, Dörth, Germany): coarse biochar, pieces of max. $0.3 \mathrm{~mm}$ diameter and $20 \mathrm{~mm}$ length, and fine biochar, milled to a particle size of $<2 \mathrm{~mm}$. Biochar characteristics can be found in Table 1; see Bamminger et al. (2016) for full details. Microscale zero-valent iron (ZVI) (Ferox-Flow, Hepure, New Jersey, USA) had a particle size ranging from $45-150 \mu \mathrm{m}$ and contained up to $2.5 \%$ 
carbon and $2 \%$ silicon. The ZVI powder had been stored for about 1.5 years previous to use and therefore its reactivity may have been somewhat reduced compared to fresh ZVI.

\subsection{Chemical characterization of soil and biochars}

The elemental composition of both soil and biochars were analyzed by inductively coupled plasma optical emission spectroscopy (Agilent Technologies 5100 ICP-OES 16/6-16, Agilent Technologies Inc., Santa Clara, USA) following microwave digestion of $0.2 \mathrm{~g}$ pulverized dried material with $5 \mathrm{ml}$ conc. $\mathrm{HNO}_{3}$ and $1 \mathrm{ml}$ of $15 \% \mathrm{H}_{2} \mathrm{O}_{2}$ in a Milestone Ultrawave microwave (Single Reaction Chamber Microwave Digestion System). pH of soil and biochar was measured in deionized water suspension, the former in a soil:water ratio of 1:2.5 $\left(w^{-1}\right)$ and the latter in a biochar:water ratio of 1:12.5 $\left.\left(w v^{-1}\right)\right)$ due to its low material density. Measurement was performed with a 913 pH meter (Metrohm, Herisau, Switzerland) after manual shaking and sedimentation for at least $30 \mathrm{~min}$. Soil texture was analyzed by a combined sedimentation and sieving method as described by Borggaard et al. (2011).

\subsection{Experimental design}

Replicate soil microcosms ( $n=4$, except $n=6$ for control treatment) were each prepared with $200 \mathrm{~g}$ air dried soil in polypropylene centrifuge bottles $(250 \mathrm{~mL})$. The following experimental treatments were established by mixing the soil homogeneously with biochar and $\mathrm{ZVI}$, in the following combinations: control (CCA contaminated soil only), $\mathrm{BC}_{\text {coarse }}$ (CCA contaminated soil $+1 \% \mathrm{w} \mathrm{w}^{-1}$ coarse biochar), $\mathrm{BC}_{\text {fine }}$ (CCA contaminated soil $+1 \% \mathrm{w} \mathrm{w}^{-1}$ fine biochar), ZVI (CCA contaminated soil $+5 \% \mathrm{w}$ $\left.\mathrm{w}^{-1} \mathrm{ZVI}\right), \mathrm{BC}_{\text {coarse }}+\mathrm{ZVI}\left(\mathrm{CCA}\right.$ contaminated soil $+1 \% \mathrm{w} \mathrm{w}^{-1}$ coarse biochar $\left.+5 \% \mathrm{w} \mathrm{w}^{-1} \mathrm{ZVI}\right)$, and $\mathrm{BC}_{\text {fine }}+$ ZVI (CCA contaminated soil $+1 \% w^{-1}$ fine biochar $\left.+5 \% w w^{-1} Z V I\right)$. Subsequently, the soils were rewetted with $20 \mathrm{~mL}$ Milli-Q water (Time 0), resulting in gravimetric water content of 10.0, 9.9, 9.5, and $9.4 \%$ for control, biochar only, ZVI only, and the combined treatments respectively, based on dry weight of soil plus amendments. Microcosms were sealed with perforated parafilm and incubated at $15{ }^{\circ} \mathrm{C}$ in the dark for up to 56 days. Soil moisture was adjusted every two to four days to ensure a 
maximum deviation from initial moisture content of $\pm 0.9 \%$ (absolute). Soil subsamples ( $7 \mathrm{~g})$ were collected from each microcosm after 1, 7, 28, and 56 days and immediately extracted and analyzed for chemical and microbiological properties (see subsequent sections below).

\subsection{Soil extraction for chemical and whole-cell bioreporter analyses}

Each microcosm soil sample was extracted with $35 \mathrm{~mL}$ Milli-Q water (i.e. soil:water-ratio 1:5) in $50 \mathrm{~mL}$ Falcon tubes by shaking for 2 hours at $200 \mathrm{rpm}$ in a horizontal position followed by centrifugation at $10000 \mathrm{~g}$ for 20 minutes. The resulting supernatant was analyzed for total water-extractable As (As $s_{\text {water }}$ ), bioavailable $\mathrm{Cu}\left(\mathrm{Cu}_{\text {bio }}\right)$, bioavailable As ( $\left.\mathrm{As}_{\text {bio }}\right)$, As redox speciation $(\mathrm{As}(\mathrm{V})$ and $\mathrm{As}(\mathrm{III}))$, pH, and dissolved organic carbon (DOC). Samples from the last sampling day were additionally analyzed for waterextractable total $\mathrm{Al}, \mathrm{As}, \mathrm{Ca}, \mathrm{Cr}, \mathrm{Cu}, \mathrm{Fe}, \mathrm{K}, \mathrm{Mg}, \mathrm{P}$, and $\mathrm{Zn}$ as described below.

\subsection{Chemical characterization of the soil-water extracts}

Aswater was determined by GF-AAS (PinAAcle $900 Z$ Atomic Absorption Spectrometer, PerkinElmer, Waltham, Massachusetts, USA) on acidified subsamples of the extract $\left(0.2 \% \mathrm{HNO}_{3}\right)$. DOC concentrations were measured with a Shimazdu TOC-VPN-analyser (Shimadzu Corp., Kyoto, Japan) on a subsample of the supernatant that had been passed through a $0.45 \mu \mathrm{m}$ cellulose acetate filter ( $\mathrm{Q}$ Max RR syringe filters, Frisenette, Denmark) that had been stored at $4{ }^{\circ} \mathrm{C}$ for a maximum of 4 weeks. $\mathrm{pH}$ was analyzed on all extracts as described for the general soil characterization (2.2).

For samples collected at the end of the experiment (Day 56), water-extractable total $\mathrm{Al}, \mathrm{As}, \mathrm{Ca}, \mathrm{Cr}, \mathrm{Cu}$, $\mathrm{Fe}, \mathrm{K}, \mathrm{Mg}, \mathrm{P}$ and $\mathrm{Zn}$ were analyzed in the water-extract $\left(3.5 \% \mathrm{HNO}_{3}\right.$ acid concentration, stored at room temperature) by ICP-OES. 

used as a constitutive control strain for taking potential sample matrix effects (e.g. masking of emitted light) into account (Brandt et al., 2008; Tom-Petersen et al., 2001). Bioavailable Cu was operationally defined as $\mathrm{Cu}$ species that were able to induce expression of Cu-regulated luxAB genes in the employed P. fluorescens DF57-Cu15 bioreporter within a $1.5 \mathrm{~h}$ incubation period. Both analysis and subsequent calculations were performed according to Brandt et al. (2008), except for final re-suspension of the biosensor cells, which was performed in a MOPS-buffered minimal medium with a low capacity for Cucomplexation (see Supporting Information Error! Reference source not found.).

Analogously, As bio was determined with Escherichia coli pJAMA arsR (Stocker et al., 2003), and E. coli pUCD 607 HB101 (Rattray et al., 1990) as a constitutive control strain. Thereby, As bioavailability was operationally defined as As species that were able to induce expression of arsenite-regulated luxAB genes in the utilized E. coli pJAMA arsR bioreporter within a $2 \mathrm{~h}$ incubation period. The bioreporter strain possesses an arsenate reductase and responds to both inorganic $\mathrm{As}(\mathrm{V})$ and $\mathrm{As}(\mathrm{III})$. Therefore, the bioreporter analysis was carried out immediately after the extraction in order to minimize possible changes in arsenic speciation. Details on the bioassay as well as calibration by As-speciation data can be found in Supporting Information B, C and Figure S1.

Although $\mathrm{As}_{\text {bio }}$ and $\mathrm{As}_{\text {water }}$ gave, on average, similar results, in this paper we focus our data presentation and analysis on the As $s_{\text {water }}$ data due to the comparably higher precision of this method (Supporting

157 Information, Figure S2). Likewise, $\mathrm{Cu}_{\text {bio }}$ and $\mathrm{Cu}_{\text {water }}$ yielded results in the same range, with about $92 \%$ of $\mathrm{Cu}_{\text {water }}$ actually being bioavailable (Figure 2B), but in this case the bioreporter data was of sufficient quality; we thus used both $\mathrm{Cu}_{\text {bio }}$ and $\mathrm{Cu}_{\text {water }}$ for data presentation and analysis. 
bioluminescence was recorded on a plate reader (FLUOStarOptima, BMG Labtech, Ortenberg, Germany) after addition of decanal as described previously (Nybroe et al., 2008).

\subsection{Bacterial growth}

Bacterial growth (i.e. heterotrophic productivity of indigenous soils bacteria) was measured using the $\left[{ }^{3} \mathrm{H}\right]$ leucine incorporation microcentrifugation technique (Bååth et al., 2001). Briefly, bacteria were extracted from soil (1 $\mathrm{g}$ fresh $\mathrm{wt}$ ) with $10 \mathrm{~mL}$ Milli-Q water on a multi-shaker at highest speed for three minutes. Following centrifugation $(1000 \times \mathrm{g}, 10 \mathrm{~min}), 1.5 \mathrm{~mL}$ aliquots of the resulting soil bacterial suspensions (supernatants) were amended with $50 \mu \mathrm{l}$ of [ $\left.{ }^{3} \mathrm{H}\right]$-labelled leucine (6.4 kBq per $50 \mu \mathrm{L}$ ) to yield a final leucine concentration of $200 \mathrm{nM}$. Incubations were terminated after either 1 or 2 hours by adding $50 \%$ trichloroacetic acid (TCA). Bacteria in dead controls were killed with $50 \%$ TCA prior to addition of $\left[{ }^{3} \mathrm{H}\right]$ leucine. Finally, the incorporated $\left[{ }^{3} \mathrm{H}\right]$ leucine was physically separated from nonincorporated $\left[{ }^{3} \mathrm{H}\right]$ leucine via a series of centrifugation and washing steps (Bååth et al., 2001) and radioactivity was measured by scintillation counting (Tri-Carb 2910 TR, Perkin-Elmer, USA). Results were normalized using the mean growth rate of the control at Day 1.

\subsection{Statistical analysis}

Statistical analyses were performed using $R$ ( $R$ version 3.3.1, The $R$ Foundation for statistical computing, 2016) and Microsoft Office Excel (Version 14.0.7166.5000, Microsoft Office Home and Student, 2010). The Imer-function was used to perform regression analysis on $\mathrm{As}_{\text {water, }} \mathrm{As}_{\text {bio, }} \mathrm{Cu}_{\text {bio, }}$ toxicity, and $\left[{ }^{3} \mathrm{H}\right]$ leucine incorporation data. The general model included the interaction between the two treatments (biochar and ZVI), considering time as fixed effect and the microcosms as random effects. Model validation was performed by qq-plotting and Shapiro-Wilk-Normality test. Except for $A s_{w a t e r}$ all statistical analyses were performed on log-transformed data. Non-significant factors and interactions were excluded from the model by step-function. Contrast-function within the Ismeans- 
package was used for deriving $\mathrm{p}$-values for pairwise comparisons. P-value adjustment for multiple comparisons was performed according to the Holm-Bonferroni-method, which controls family-wise error rate (Holm, 1979). For the data from the ICP-OES analysis (water-extractable total metals at the last sampling time), two-way ANOVA (aov-function) was performed, since no time effect had to be considered. As for the other analyses, the Shapiro-Wilk Test was performed to check for normality. Only analysis of $\mathrm{Cr}$-data was performed on log-transformed data, while raw data was used for all other elements. P-values for statistically significant differences between the treatments were derived using TukeyHSD test. Throughout, a significance level of $p<0.05$ was applied.

\subsection{Treatment effects on soil chemical properties and bioavailability of As and $\mathrm{Cu}$}

In general, the combined treatment of $\mathrm{ZVI}$ with $\mathrm{BC}_{\text {fine }}$ was most effective in reducing $\mathrm{As}_{\text {water }}, \mathrm{Cu}_{\text {water, }}$, and $\mathrm{Cr}_{\text {water }}$ by $43 \%, 45 \%$, and $45 \%$, respectively, compared to the control and measured after 56 days (Figure 1). Looking into the effects of the separate treatments, $\mathrm{ZVI}$ alone also reduced the three elements, but to a lesser extent: $\mathrm{As}_{\text {water }}$ was reduced by $27 \%$ while $\mathrm{Cu}_{\text {water }}$ was reduced by $29 \%$ compared to the control $(\mathrm{p}<0.001)$. In addition, $\mathrm{Cr}$ was significantly reduced by $\mathrm{ZVI}$ alone by $39 \%$, resulting in a concentration of $0.40 \mu \mathrm{g} \mathrm{g}^{-1} \mathrm{dry}$ soil $(\mathrm{p}<0.05)$. Biochar alone did not have a significant effect on the extractability of any of the elements. Nevertheless, biochar affected the bioavailability of $\mathrm{Cu}$ (Figure 2). At Day 1 and Day 7, $\mathrm{Cu}_{\text {bio }}$ was significantly reduced by $\mathrm{BC}_{\text {fine, }}(\mathrm{p}=0.014$ and $p=0.004$, respectively) (Figure 2A). This was also observed at the end of the incubation period, but the effect was not statistically significant. In contrast to $\mathrm{CU}_{\text {water, }}$ which was reduced by $\mathrm{ZVI}$ as mentioned above, $\mathrm{CU}_{\text {bio }}$ was not affected by ZVI alone (Figure 2B).

Soil amendments also affected other chemical soil properties. On average, treatment with biochar increased pH from $6.4 \pm 0.04$ to about $6.7 \pm 0.07$ both with and without ZVI (Day 1). DOC decreased after the first sampling and generally was very low $\left(<8 \mathrm{mg} \mathrm{L}^{-1}\right)$ (data shown in supporting information, 
Figure S3). As there was an analytical problem with some of the blanks, interpretation of the data must be treated cautiously; however, it seems that both biochar and ZVI slightly reduced DOC (except for sampling at Day 56).

Treatments with biochar and/or ZVI also affected other elements, as summarized in Table 2. Biochar significantly increased water extractable fractions of $P$ and $K(p<0.01$ and $p<0.001)$, and significantly reduced possible toxic elements such as $\mathrm{Al}$ and $\mathrm{Zn}(\mathrm{p}<0.001)$. ZVI enhanced the reductions in $\mathrm{Al}$ and Zn content in the extract; however, it also reduced P. In addition, ZVI strongly reduced extractable Fe and Mg.

In general, soil amendment effects on soil chemistry were remarkably stable over time. Hence, $A s_{\text {water }}$ (Supporting Information, Figure S2), $\mathrm{Cu}_{\text {bio }}$ (Figure 2A), $\mathrm{pH}$ (data not shown) and As speciation (Supporting Information, Figure S1) did not exhibit any statistically significant changes during the experimental period of 56 days.

\subsection{Effects of soil amendments on soil toxicity}

Treatments did not have any consistent effect on toxicity of the soil-water extracts as assessed by the bioreporter assay with E. coli pUCD 607 HB101 (Supporting Information, Figure S4). ZVI increased the relative response of the bioreporter; however, the effect was only statistically significant at Day 7 . No general trends over time could be observed.

\subsection{Treatment effects on bacterial growth rate}

$227\left[{ }^{3} \mathrm{H}\right]$ leucine incorporation increased markedly from Day 1 to the subsequent sampling days (Figure 3). 228 At the last two sampling times (Day 28 and Day 56), biochar significantly increased bacterial growth 229 rate irrespective of whether or not ZVI was present $(p<0.001$ at Day $28, p<0.005$ at Day 56$)$. ZVI slightly increased $\left[{ }^{3} \mathrm{H}\right]$ leucine incorporation as well, but the effect was not statistically significant. These effects could not be seen at the earlier samplings; instead, the opposite was observed: At Day 
2321 , biochar significantly reduced bacterial growth rate compared to the treatments without biochar ( $p$ $233<0.001)$.

\subsection{Effects of soil amendments on soil quality}

To the best of our knowledge, our study is the first to investigate in-situ stabilization with both biochar and ZVI for remediation of a CCA-contaminated soil and to assess soil quality recovery using a TRIAD approach with three lines of evidence: chemistry, (eco)toxicology, and ecology. In our study, the (eco)toxicology line of evidence (bioluminescence inhibition assay) was insensitive to changes imposed by the experimental treatments and soil quality was best assessed by the other two lines of evidence. Our study thus demonstrates the value of using the $\left[{ }^{3} \mathrm{H}\right]$ leucine incorporation assay as a sensitive ecological indicator of soil quality recovery and argues against sole reliance on classical ecotoxicological short-term assays with introduced test organisms. A pronounced increase in bacterial growth during the first weeks of the study was observed for all treatments, including the control, and was certainly a rewetting effect (Meisner et al., 2015), as the soil had been air-dried prior to setting up the microcosm experiment.

As hypothesized, we found that fine biochar in combination with ZVI was the most effective treatment to significantly decrease the risks posed by $\mathrm{As}, \mathrm{Cu}$ and $\mathrm{Cr}$. Hence, chemical and ecological lines of evidence consistently indicated that the combination of $\mathrm{BC}_{\text {fine }}$ and $\mathrm{ZVI}$ was the most effective treatment for reducing exposure and bioavailability of metals (Figures 1 and 2) and restoring the ecological functionality of the soil (Figure 3). The latter claim is based on the assumption that an increase in secondary bacterial productivity as measured by the $\left[{ }^{3} \mathrm{H}\right]$ leucine incorporation technique is indicative of ecological recovery. Generally, treatments with milled biochar $\left(\mathrm{BC}_{\text {fine }}\right)$ have invoked a greater effect as compared with coarse biochar, likely due to its provision of additional sorption sites due to smaller 
particle size and increased surface area. Nevertheless, the observed treatment effects were moderate and As and Cu concentrations in the water extract (Figure 1) still exceeded Danish groundwater quality criteria, by 185-fold and approximately 4-fold, respectively (Danish EPA, 2002). These were chosen as reference criteria because no general guidelines for water-extractable concentrations exist. Other studies that have explored the use of novel iron-modified biochars have found them to be comparable, or even more effective at reducing extractable fractions of As (Qiao et al., 2018; C. Wu et al., 2018), Cu (Yang et al., 2018a), or Cr (Lyu et al., 2018; Mandal et al., 2017; Zhang et al., 2017); however, none of them looked into the combined effect on CCA-contaminated soil.

Regarding the isolated effect of ZVI, our study is consistent with previous soil studies demonstrating the ability of ZVI to stabilize Cr, Cu and As (Kumpiene et al., 2006; Nielsen et al., 2016, 2011; Sneath et al., 2013). With respect to As specifically, our reported two-fold decrease in water-extractable As is consistent with Sneath et al. (2013), but much lower than the 93 and $98 \%$ reductions in leachable As reported by other aforementioned studies. These findings suggest that the efficacy of the remediation treatment is highly dependent on the quality and specific properties of the amendment. We also found that while water-extractable $\mathrm{Cu}$ decreased after treatment with $\mathrm{ZVI}$, albeit less strongly than seen in the above studies, bioavailable $\mathrm{Cu}$ did not. Similarly, Kumpiene et al. (2006) reported a decrease in pore water concentrations of $\mathrm{Cu}$ after treatment with ZVI, but pointed out that ZVI did not reduce bioaccessible $\mathrm{Cu}$ (determined by sequential extraction) and in fact, even increased plant uptake. Generally, we observed a low water-extractability of $\mathrm{Cr}$, likely because $\mathrm{Cr}$ at this site was reported to be present almost exclusively in the form of $\mathrm{Cr}$ (III) (Nielsen et al., 2016) and primarily associated with hard-to-extract Fe oxides in the oxic top soil (Tardif et al., 2019). In accordance with others, we also observed a significant reduction in water-extractable Cr upon addition of ZVI (Nielsen et al., 2011; Sneath et al., 2013; Zhang et al., 2018), probably due to provision of additional sorption sites on Fe(hydr)oxide surfaces for $\mathrm{Cr}(\mathrm{III})$ (Fendorf, 1995; Kumpiene et al., 2006). Concomitant with the effects of 
ZVI on soil chemistry, ZVI amendment reduced toxicity only slightly as indicated by the $E$. coli pUCD 607 HB101 biosensor assay and did not significantly increase $\left[{ }^{3} \mathrm{H}\right]$ leucine incorporation rates.

Biochar amendments alone did not substantially reduce concentrations of water-extractable elements, in contrast to earlier findings (Beesley et al., 2014; Mitchell et al., 2018; Sneath et al., 2013; Uchimiya et al., 2011a), but as expected, biochar did significantly reduce Cu bioavailability. Likewise, a previous study found that biochar addition to a sandy soil did not alter water-extractable Cu although it did reduce Cu phytoavailability (Namgay et al., 2010). Our study thus demonstrated that although biochar was generally less effective than ZVI in reducing water-extractable concentrations of the contaminants, it was more effective in reducing bioavailable $\mathrm{Cu}$. This may possibly explain why bacterial growth was more effectively restored with biochar than under ZVI treatment (Figure 3). Hence, Cu most likely represented the most toxic element in the studied CCA contaminated soil (Tardif et al., unpublished results) and bioavailable $\mathrm{Cu}$ determined with the $P$. fluorescens bioreporter used here has previously been shown to constitute an excellent predictor of $\mathrm{Cu}$ toxicity effects in soil bacterial communities (Nunes et al., 2016; Song et al., 2017). Our findings are also in accordance with a recent study showing that biochar amendment restored microbial activity in Cu contaminated soil (Moore et al., 2018). A number of factors, such as soil properties (e.g. pH, texture, or CEC (Uchimiya et al., 2011a)), biochar properties (e.g. pyrolysis temperature (Uchimiya et al., 2011b)), redox conditions (El-Naggar et al., 2018), and/or Cu-concentrations in soil (Ippolito et al., 2012; Lu et al., 2017; Mackie et al., 2015) influence Cu water extractability and bioavailability in soil after biochar addition. As soil DOC was very low and soil $\mathrm{pH}$ was near neutral in our study, it is plausible that biochar influences were relatively small and not as pronounced as seen in studies with more acidic soils (Beesley et al., 2014; Uchimiya et al., 2011a). In contrast to previous literature (Choppala et al., 2015), we did not see any effect of biochar on $\mathrm{Cr}_{\text {water. }}$ This is likely to have been due to a high fraction of the total $\mathrm{Cr}$ having already been reduced and stabilized in soil oxide minerals (Nielsen et al., 2016, 2011; Tardif et al., 2019) (see above discussion on effects of $\mathrm{ZVI}$ ) and therefore, no additional effects of the treatment could be observed. 
Although our study cannot provide clear predictions of long-term field applicability of ZVI and biochar amendments for remediation of CCA contaminated soils, it demonstrated that treatment effects on soil chemical parameters remained quite stable over time. The effects of remediation treatments on both $\mathrm{Cu}$ and As bioavailability were detectable after only one day, indicating that oxidation and sorption reactions must have occurred during the first 24 hours, as previously shown (Jain et al., 1999; Nielsen et al., 2011). Long-term efficacy of ZVI has been previously suggested by Tiberg et al. (2016) who argued that the effect of ZVI on As leaching and mobility should remain stable over at least up to 15 years. In contrast, the efficacy of biochar may be more short-lived, as shown in our study by the fact that significant reduction in $\mathrm{Cu}$ bioavailability $\left(\mathrm{Cu}_{\text {bio }}\right)$ was only observed during the first week. This raises the question of whether or not the observed biochar effect would diminish over time. Also, organic acids released from plants grown at a site could potentially lead to a release of Cu from biochar (Oustriere et al., 2017), which would be problematic, since long-term stability of the amendments is crucial for remediation. Furthermore, flooding, which was frequently observed at this study site, could be problematic; under anaerobic conditions biochar has been shown to enhance As mobilization, possibly by acting as an electron shuttle (Kappler et al., 2014; Wang et al., 2017). This was shown to be of particular concern for biochar produced at high pyrolysis temperatures (Beiyuan et al., 2017).

\subsection{Comparison of chemical and microbiological measurements of bioavailability of Cu and As}

Assessment of bioavailable element fractions depends on the underlying definition of "bioavailability" (Semple et al., 2004) and should not be assessed solely by chemical analysis (Kumpiene et al., 2017; Touceda-Gonzalez et al., 2017). Since in-situ stabilization of contaminated sites relies on reducing the bioavailability of contaminants, we complemented soil chemical analysis with whole-cell biosensors specific for both $\mathrm{As}$ and $\mathrm{Cu}$, but not for $\mathrm{Cr}$, as no biosensor was available. In our study, biosensor analysis generally yielded concentrations in the same range as chemical analysis, implying that all dissolved $\mathrm{Cu}$ and As species remained bioavailable (Supporting Information, Figure S2 and Figure 2). This suggests that under the given conditions, water-extractable fractions of both, As and Cu roughly 
reflected the bioavailable, and thus toxicologically most relevant fractions. Nevertheless, the deviation between $A s_{\text {water }}$ and $A s_{\text {bio }}$ appeared rather random and could not be explained by any systematic effect, but instead likely revealed the sensitivity of the bioassay to other soil properties. Specific interferences with the As biosensor could be changes in As redox speciation, presence of other elements such as Fe or P (e.g. Kuppardt, 2010; Trang et al., 2005), influence of co-contaminants, and other general matrix effects such as changes in $\mathrm{pH}$. Hence, we suggest that further optimization of the As biosensor assay for contaminated soils is needed. On the other hand, $\mathrm{Cu}_{\text {bio }}$ measured with the $\mathrm{Cu}$ biosensor did not significantly exceed $\mathrm{Cu}_{\text {water, }}$ but instead showed a consistent trend in the effects of the treatments on $\mathrm{Cu}_{\text {bio. }}$. These findings suggest that the $\mathrm{Cu}$ biosensor reliably assessed $\mathrm{Cu}$ bioavailability even in the studied multi-element contaminated soil (Figure 2). Consistent with previous studies, which showed even larger deviations between $\mathrm{Cu}_{\text {bio }}$ and $\mathrm{Cu}_{\text {water }}$ especially for samples with higher DOC content (Brandt et al., 2008; Maderova et al., 2011; Nybroe et al., 2008), findings from our study further confirm the usefulness of complementing chemical measurements with bacterial biosensor data to infer Cu bioavailability in contaminated soils.

\subsection{Concluding remarks}

We conclude that combined application of biochar and ZVI as soil amendments holds promise for insitu stabilization of CCA contaminated sites and for the ecological recovery of soil microbiota at these sites. As treatment effects were less pronounced than in other studies, we suggest that future attempts to use these types of amendments for in-situ stabilization of multi-element contaminated sites should focus on the quality and properties of biochar, ZVI, and novel iron-biochar composites to ensure optimization of remediation. Further research should focus on the long-term stability of these amendments, their field applicability, and on replicability of the results with other types of biochar and different soils. More studies are needed to evaluate whether the achieved improvement in soil quality is sufficient to enable plant growth, and thereby to serve, as suggested previously (e.g. de Oliveira et al., 2017; Sneath et al., 2013), as a first step towards further remediation. 


\section{Acknowledgments}

355 This study originated from a Master of Science thesis in the framework of the Euroleague for Life

356 Sciences (ELLS). The authors would like to thank Dr. Sven Marhan from the University of Hohenheim,

357 Stuttgart, Germany, for providing biochar samples and the necessary background data on them, and

358

Dr. Kathleen Regan for English proofreading.

359 This project has received funding from the European Union's Horizon 2020 research and innovation

360 program under the Marie Sklodowska-Curie grant agreement No. 643087. 
Amternes Videncenter for Jordforurening, 1997. Branchevejledning for træimprægneringsvirksomheder (in Danish).English title: Guidelines for wood impregnation companies: Teknik og Administration 10.

Arthur, E., Moldrup, P., Holmstrup, M., Schjønning, P., Winding, A., Mayer, P., de Jonge, L.W., 2012. Soil microbial and physical properties and their relations along a steep copper gradient. Agric. Ecosyst. Environ. 159, 9-18. https://doi.org/10.1016/j.agee.2012.06.021

Ashbolt, N.J., Amézquita, A., Backhaus, T., Borriello, P., Brandt, K.K., Collignon, P., Coors, A., Finley, R., Gaze, W.H., Heberer, T., 2013. Human health risk assessment (HHRA) for environmental development and transfer of antibiotic resistance. Environ. Health Perspect. 121, 993.

Bååth, E., Pettersson, M., Söderberg, K.H., 2001. Adaptation of a rapid and economical microcentrifugation method to measure thymidine and leucine incorporation by soil bacteria. Soil Biol. Biochem. 33, 1571-1574. https://doi.org/10.1016/S0038-0717(01)00073-6

Bakshi, S., Banik, C., Rathke, S.J., Laird, D.A., 2018. Arsenic sorption on zero-valent iron-biochar complexes. WATER Res. 137, 153-163. https://doi.org/10.1016/j.watres.2018.03.021

Bamminger, C., Poll, C., Sixt, C., Högy, P., Wüst, D., Kandeler, E., Marhan, S., 2016. Short-term response of soil microorganisms to biochar addition in a temperate agroecosystem under soil warming. Agriculture, Ecosystems and Environment, 308-317.

Beesley, L., Inneh, O.S., Norton, G.J., Moreno-Jimenez, E., Pardo, T., Clemente, R., Dawson, J.J.C., 2014. Assessing the influence of compost and biochar amendments on the mobility and toxicity of metals and arsenic in a naturally contaminated mine soil. Environ. Pollut. 186, 195-202. https://doi.org/10.1016/j.envpol.2013.11.026

Beesley, L., Moreno-Jiménez, E., Gomez-Eyles, J.L., 2010. Effects of biochar and greenwaste compost amendments on mobility, bioavailability and toxicity of inorganic and organic contaminants in a multi-element polluted soil. Adv. Air Pollut. Sci. For. Decline Mult.-Stress Eff. For. Ecosyst. Serv. 158, 2282-2287. https://doi.org/10.1016/j.envpol.2010.02.003

Beesley, L., Moreno-Jiménez, E., Gomez-Eyles, J.L., Harris, E., Robinson, B., Sizmur, T., 2011. A review of biochars' potential role in the remediation, revegetation and restoration of contaminated soils. Environ. Pollut. 159, 3269-3282.

Beiyuan, J., Awad, Y.M., Beckers, F., Tsang, D.C.W., Ok, Y.S., Rinklebe, J., 2017. Mobility and phytoavailability of $\mathrm{As}$ and $\mathrm{Pb}$ in a contaminated soil using pine sawdust biochar under systematic change of redox conditions. Chemosphere 178, 110-118. https://doi.org/10.1016/j.chemosphere.2017.03.022

Bhattacharya, P., Frisbie, S.H., Smith, E., Naidu, R., Jacks, G., Sarkar, B., 2002. Arsenic in the environment: a global perspective. Heavy Met. Environ. Sarkar B Ed N. Y. Marcel Dekker Inc 147-215.

Bolan, N., Kunhikrishnan, A., Thangarajan, R., Kumpiene, J., Park, J., Makino, T., Kirkham, M.B., Scheckel, K., 2014. Remediation of heavy metal(loid)s contaminated soils - To mobilize or to immobilize? J. Hazard. Mater. 266, 141-166. https://doi.org/10.1016/j.jhazmat.2013.12.018

Borggaard, O.K., Kristiansen, S.M., Rasmussen, C., Knadel, M., Knudsen, L., 2011. Teksturanalyse: Metoder og udfordringer. Jordanalyser 73.

Brandt, K.K., Amézquita, A., Backhaus, T., Boxall, A., Coors, A., Heberer, T., Lawrence, J.R., Lazorchak, J., Schönfeld, J., Snape, J.R., Zhu, Y.-G., Topp, E., 2015. Ecotoxicological assessment of antibiotics: A call for improved consideration of microorganisms. Environ. Int. 85, 189-205. https://doi.org/10.1016/j.envint.2015.09.013.

Brandt, K.K., Holm, P.E., Nybroe, O., 2008. Evidence for Bioavailable Copper- Dissolved Organic Matter Complexes and Transiently Increased Copper Bioavailability in Manure-Amended 
Soils as Determined by Bioluminescent Bacterial Biosensors. Environ. Sci. Technol. 42, 31023108.

Buss, W., Kammann, C., Koyro, H.-W., 2012. Biochar Reduces Copper Toxicity in Chenopodium quinoa Willd. in a Sandy Soil. J. Environ. Qual. 41, 1157-1165. https://doi.org/10.2134/jeq2011.0022

Choppala, G., Bolan, N., Kunhikrishnan, A., Skinner, W., Seshadri, B., 2015. Concomitant reduction and immobilization of chromium in relation to its bioavailability in soils. Environ. Sci. Pollut. Res. 22, 8969-8978.

de Oliveira, L.M., Suchismita, D., Gress, J., Rathinasabapathi, B., Chen, Y., Ma, L.Q., 2017. Arsenic uptake by lettuce from As-contaminated soil remediated with Pteris vittata and organic amendment. CHEMOSPHERE 176, 249-254. https://doi.org/10.1016/j.chemosphere.2017.02.124

Diao, Z.-H., Du, J.-J., Jiang, D., Kong, L.-J., Huo, W.-Y., Liu, C.-M., Wu, Q.-H., Xu, X.-R., 2018. Insights into the simultaneous removal of $\mathrm{Cr} 6+$ and $\mathrm{Pb} 2+$ by a novel sewage sludge-derived biochar immobilized nanoscale zero valent iron: Coexistence effect and mechanism. Sci. TOTAL Environ. 642, 505-515. https://doi.org/10.1016/j.scitotenv.2018.06.093

El-Naggar, A., Shaheen, S.M., Ok, Y.S., Rinklebe, J., 2018. Biochar affects the dissolved and colloidal concentrations of $\mathrm{Cd}, \mathrm{Cu}, \mathrm{Ni}$, and $\mathrm{Zn}$ and their phytoavailability and potential mobility in a mining soil under dynamic redox-conditions. Sci. Total Environ. 624, 1059-1071. https://doi.org/10.1016/j.scitotenv.2017.12.190

European Commission, 2003. Commission Directive 2003/2/EC of 6 January 2003 relating to restrictions on the marketing and use of arsenic (tenth adaptation to technical progress to Council Directive 76/769/EEC). Official Journal of the European Communities, Brussels.

Fendorf, S.E., 1995. Surface reactions of chromium in soils and waters. Geoderma 67, 55-71.

Hartley, W., Dickinson, N.M., Riby, P., Lepp, N.W., 2009. Arsenic mobility in brownfield soils amended with green waste compost or biochar and planted with Miscanthus. Environ. Pollut. 157, 2654-2662. https://doi.org/10.1016/j.envpol.2009.05.011

He, R., Peng, Z., Lyu, H., Huang, H., Nan, Q., Tang, J., 2018. Synthesis and characterization of an ironimpregnated biochar for aqueous arsenic removal. Sci. Total Environ. 612, 1177-1186.

Holm, S., 1979. A simple sequentially rejective multiple test procedure. Scand. J. Stat. 65-70.

Hopp, L., Peiffer, S., Durner, W., 2006. Spatial variability of arsenic and chromium in the soil water at a former wood preserving site. J. Contam. Hydrol. 85, 159-178.

Humphrey, D.G., 2002. The chemistry of chromated copper arsenate wood preservatives. Rev. Inorg. Chem. 22, 1-40.

Ippolito, J.A., Strawn, D.G., Scheckel, K.G., Novak, J.M., Ahmedna, M., Niandou, M.A.S., 2012. Macroscopic and Molecular Investigations of Copper Sorption by a Steam-Activated Biochar. J. Environ. Qual. 41, 1150. https://doi.org/10.2134/jeq2011.0113

ISO 19204, 2017. Soil quality - Procedure for site-specific ecological risk assessment of soil contamination (soil quality TRIAD approach).

Kappler, A., Wuestner, M.L., Ruecker, A., Harter, J., Halama, M., Behrens, S., 2014. Biochar as an electron shuttle between bacteria and Fe (III) minerals. Environ. Sci. Technol. Lett. 1, 339344.

Kim, H.-B., Kim, S.-H., Jeon, E.-K., Kim, D.-H., Tsang, D.C.W., Alessi, D.S., Kwon, E.E., Baek, K., 2018. Effect of dissolved organic carbon from sludge, Rice straw and spent coffee ground biochar on the mobility of arsenic in soil. Sci. Total Environ. 636, 1241-1248. https://doi.org/10.1016/j.scitotenv.2018.04.406

Kolodynska, D., Bak, J., 2018. Use of three types of magnetic biochar in the removal of copper(II) ions from wastewaters. Sep. Sci. Technol. 53, 1045-1057. https://doi.org/10.1080/01496395.2017.1345944

Kumpiene, J., Giagnoni, L., Marschner, B., Denys, S., Mench, M., Adriaensen, K., Vangronsveld, J., Puschenreiter, M., Renella, G., 2017. Assessment of Methods for Determining Bioavailability 
of Trace Elements in Soils: A Review. PEDOSPHERE 27, 389-406. https://doi.org/10.1016/S1002-0160(17)60337-0

Kumpiene, J., Lagerkvist, A., Maurice, C., 2008. Stabilization of As, Cr, Cu, Pb and $\mathrm{Zn}$ in soil using amendments - A review. Waste Manag. 28, 215-225. https://doi.org/10.1016/j.wasman.2006.12.012

Kumpiene, J., Ore, S., Renella, G., Mench, M., Lagerkvist, A., Maurice, C., 2006. Assessment of zerovalent iron for stabilization of chromium, copper, and arsenic in soil. Environ. Pollut. 144, 62-69.

Kuppardt, A., 2010. Improvement of Bioreporter Bacteria Based Test Systems for the Analysis of Arsenic in Drinking Water and the Rhizosphere. UFZ.

Lehmann, J., Joseph, S., 2015. Biochar for environmental management: science, technology and implementation. Routledge.

Lu, K., Yang, X., Gielen, G., Bolan, N., Ok, Y.S., Niazi, N.K., Xu, S., Yuan, G., Chen, X., Zhang, X., Liu, D., Song, Z., Liu, X., Wang, H., 2017. Effect of bamboo and rice straw biochars on the mobility and redistribution of heavy metals $(\mathrm{Cd}, \mathrm{Cu}, \mathrm{Pb}$ and $\mathrm{Zn})$ in contaminated soil. Biogeochem. Trace Elem. Environ. 186, 285-292. https://doi.org/10.1016/j.jenvman.2016.05.068

Lyu, H., Zhao, H., Tang, J., Gong, Y., Huang, Y., Wu, Q., Gao, B., 2018. Immobilization of hexavalent chromium in contaminated soils using biochar supported nanoscale iron sulfide composite. CHEMOSPHERE 194, 360-369. https://doi.org/10.1016/j.chemosphere.2017.11.182

Mackie, K.A., Marhan, S., Ditterich, F., Schmidt, H.P., Kandeler, E., 2015. The effects of biochar and compost amendments on copper immobilization and soil microorganisms in a temperate vineyard. Agric. Ecosyst. Environ. 201, 58-69. https://doi.org/10.1016/j.agee.2014.12.001

Maderova, L., Watson, M., Paton, G.I., 2011. Bioavailability and toxicity of copper in soils: Integrating chemical approaches with responses of microbial biosensors. Soil Biol. Biochem. 43, 11621168.

Mandal, S., Sarkar, B., Bolan, N., Ok, Y.S., Naidu, R., 2017. Enhancement of chromate reduction in soils by surface modified biochar. J. Environ. Manage. 186, 277-284. https://doi.org/10.1016/j.jenvman.2016.05.034

Masscheleyn, P.H., Delaune, R.D., Patrick, W.H., 1991. Effect of redox potential and pH on arsenic speciation and solubility in a contaminated soil. Environ. Sci. Technol. 25, 1414-1419. https://doi.org/10.1021/es00020a008

Maurice, C., Lidelöw, S., Gustavsson, B., Lättström, A., Ragnvaldsson, D., Leffler, P., Lövgren, L., Tesfalidet, S., Kumpiene, J., 2007. Techniques for the stabilization and assessment of treated copper-, chromium-, and arsenic-contaminated soil. AMBIO J. Hum. Environ. 36, 430-436.

Meisner,A., Rousk,J., Bååth,E., 2015. Prolonged drought changes the bacterial growth response to rewetting. Soil Biol. Biochem. 88, 314-322.

Miretzky, P., Cirelli, A.F., 2010. Remediation of arsenic-contaminated soils by iron amendments: a review. Crit. Rev. Environ. Sci. Technol. 40, 93-115.

Mitchell, K., Trakal, L., Sillerova, H., Javier Avelar-Gonzalez, F., Lilian Guerrero-Barrera, A., Hough, R., Beesley, L., 2018. Mobility of As, $\mathrm{Cr}$ and $\mathrm{Cu}$ in a contaminated grassland soil in response to diverse organic amendments; a sequential column leaching experiment. Appl. Geochem. 88, 95-102. https://doi.org/10.1016/j.apgeochem.2017.05.020

Moore, F., González, M.-E., Khan, N., Curaqueo, G., Sanchez-Monedero, M., Rilling, J., Morales, E., Panichini, M., Mutis, A., Jorquera, M., Mejias, J., Hirzel, J., Meier, S., 2018. Copper immobilization by biochar and microbial community abundance in metal-contaminated soils. Sci. Total Environ. 616-617, 960-969. https://doi.org/10.1016/j.scitotenv.2017.10.223

Namgay, T., Singh, B., Singh, B.P., 2010. Influence of biochar application to soil on the availability of As, $\mathrm{Cd}, \mathrm{Cu}, \mathrm{Pb}$, and $\mathrm{Zn}$ to maize (Zea mays L.). Soil Res. 48, 638-647.

Namiesnik, J., Rabajczyk, A., 2012. Speciation Analysis of Chromium in Environmental Samples. Crit. Rev. Environ. Sci. Technol. 42, 327-377. https://doi.org/10.1080/10643389.2010.518517 
Nielsen, S.S., 2013. Stabilization of arsenic and chromium polluted soils using water treatment residues. Technical University of DenmarkDanmarks Tekniske Universitet, Department of Environmental Science and EngineeringInstitut for Miljøteknologi.

Nielsen, S.S., Jakobsen, Rasmus, Kjeldsen, Peter, 2010. Lokalitet nr. 291-3 Collstrupgrunden Udredning vedr. forurenigssituationen på og omkring grunden 1977 - 2009 (in Danish). English title: Site no. 219-3 Collstrup - Review on the pollution at and around the site 1977 2009. The Capital Region of Denmark. DTU Miljø.

Nielsen, S.S., Kjeldsen, P., Jakobsen, R., 2016. Full scale amendment of a contaminated wood impregnation site with iron water treatment residues. Front. Environ. Sci. Eng. 10, 1-10.

Nielsen, S.S., Petersen, L.R., Kjeldsen, P., Jakobsen, R., 2011. Amendment of arsenic and chromium polluted soil from wood preservation by iron residues from water treatment. Chemosphere 84, 383-389. https://doi.org/10.1016/j.chemosphere.2011.03.069

Nunes, I., Jacquiod, S., Brejnrod, A., Holm, P.E., Johansen, A., Brandt, K.K., Priemé, A., Sørensen, S.J., 2016. Coping with copper: legacy effect of copper on potential activity of soil bacteria following a century of exposure. FEMS Microbiol. Ecol. 92. https://doi.org/10.1093/femsec/fiw175

Nybroe, O., Brandt, K.K., Ibrahim, Y.M., Tom-Petersen, A., Holm, P.E., 2008. Differential bioavailability of copper complexes to bioluminescent Pseudomonas fluorescens reporter strains. Environ. Toxicol. Chem. 27, 2246-2252.

Oustriere, N., Marchand, L., Lottier, N., Motelica, M., Mench, M., 2017. Long-term Cu stabilization and biomass yields of Giant reed and poplar after adding a biochar, alone or with iron grit, into a contaminated soil from a wood preservation site. Sci. Total Environ. 579, 620-627. https://doi.org/10.1016/j.scitotenv.2016.11.048

Peters, G.R., McCurdy, R.F., Hindmarsh, J.T., 1996. Environmental aspects of arsenic toxicity. Crit. Rev. Clin. Lab. Sci. 33, 457-493.

Qiao, J., Liu, T., Wang, X., Li, F., Lv, Y., Cui, J., Zeng, X., Yuan, Y., Liu, C., 2018. Simultaneous alleviation of cadmium and arsenic accumulation in rice by applying zero-valent iron and biochar to contaminated paddy soils. CHEMOSPHERE 195, 260-271. https://doi.org/10.1016/j.chemosphere.2017.12.081

Rattray, E.A., Prosser, J.I., Killham, K., Glover, L.A., 1990. Luminescence-based nonextractive technique for in situ detection of Escherichia coli in soil. Appl. Environ. Microbiol. 56, 33683374.

Semple, K.T., Doick, K.J., Jones, K.C., Burauel, P., Craven, A., Harms, H., 2004. Peer Reviewed: Defining Bioavailability and Bioaccessibility of Contaminated Soil and Sediment is Complicated. Environ. Sci. Technol. 38, 228A-231A. https://doi.org/10.1021/es040548w

Silvetti, M., Castaldi, P., Holm, P.E., Deiana, S., Lombi, E., 2014. Leachability, bioaccessibility and plant availability of trace elements in contaminated soils treated with industrial by-products and subjected to oxidative/reductive conditions. Geoderma 214, 204-212.

Sneath, H.E., Hutchings, T.R., de Leij, F.A.A.M., 2013. Assessment of biochar and iron filing amendments for the remediation of a metal, arsenic and phenanthrene co-contaminated spoil. Environ. Pollut. 178, 361-366. https://doi.org/10.1016/j.envpol.2013.03.009

Song, J., Rensing, C., Holm, P.E., Virta, M., Brandt, K.K., 2017. Comparison of Metals and Tetracycline as Selective Agents for Development of Tetracycline Resistant Bacterial Communities in Agricultural Soil. Environ. Sci. Technol. 51, 3040-3047.

Stocker, J., Balluch, D., Gsell, M., Harms, H., Feliciano, J., Daunert, S., Malik, K.A., van der Meer, J.R., 2003. Development of a set of simple bacterial biosensors for quantitative and rapid measurements of arsenite and arsenate in potable water. Environ. Sci. Technol. 37, 47434750. 
Tardif, S., Cipullo, S., Helle, S.U., Wragg, J., Holm, P.E., Coulon, F., Brandt, K.K., Cave, M., 2019. Factors governing the solid phase distribution of $\mathrm{Cr}, \mathrm{Cu}$ and $\mathrm{As}$ in contaminated soil after 40 years of ageing. Sci. Total Environ. https://doi.org/10.1016/j.scitotenv.2018.10.244.

Tom-Petersen, A., Hosbond, C., Nybroe, O., 2001. Identification of copper-induced genes in Pseudomonas fluorescens and use of a reporter strain to monitor bioavailable copper in soil. FEMS Microbiol. Ecol. 38, 59-67.

Touceda-Gonzalez, M., Prieto-Fernandez, A., Renella, G., Giagnoni, L., Sessitsch, A., Brader, G., Kumpiene, J., Dimitriou, I., Eriksson, J., Friesl-Hanl, W., Galazka, R., Janssen, J., Mench, M., Mueller, I., Neu, S., Puschenreiter, M., Siebielec, G., Vangronsveld, J., Kidd, P.S., 2017. Microbial community structure and activity in trace element-contaminated soils phytomanaged by Gentle Remediation Options (GRO). Environ. Pollut. 231, 237-251. https://doi.org/10.1016/j.envpol.2017.07.097

Trang, P.T.K., Berg, M., Viet, P.H., Mui, N.V., van der Meer, J.R., 2005. Bacterial bioassay for rapid and accurate analysis of arsenic in highly variable groundwater samples. Environ. Sci. Technol. 39, 7625-7630.

Uchimiya, M., Klasson, K.T., Wartelle, L.H., Lima, I.M., 2011a. Influence of soil properties on heavy metal sequestration by biochar amendment: 1 . Copper sorption isotherms and the release of cations. Chemosphere 82, 1431-1437. https://doi.org/10.1016/j.chemosphere.2010.11.050

Uchimiya, M., Wartelle, L.H., Klasson, K.T., Fortier, C.A., Lima, I.M., 2011b. Influence of Pyrolysis Temperature on Biochar Property and Function as a Heavy Metal Sorbent in Soil. J. Agric. Food Chem. 59, 2501-2510. https://doi.org/10.1021/jf104206c

U.S. EPA, 2002. Manufacturers to Use New Wood Preservatives, Replacing Most Residential Uses of CCA.

Wang, N., Xue, X.-M., Juhasz, A.L., Chang, Z.-Z., Li, H.-B., 2017. Biochar increases arsenic release from an anaerobic paddy soil due to enhanced microbial reduction of iron and arsenic. Environ. Pollut. 220, 514-522. https://doi.org/10.1016/j.envpol.2016.09.095

Wu, B., Peng, D., Hou, S., Tang, B., Wang, C., Xu, H., 2018. Dynamic study of Cr(VI) removal performance and mechanism from water using multilayer material coated nanoscale zerovalent iron. Environ. Pollut. 240, 717-724. https://doi.org/10.1016/j.envpol.2018.04.099

Wu, C., Cui, M., Xue, S., Li, W., Huang, L., Jiang, X., Qian, Z., 2018. Remediation of arseniccontaminated paddy soil by iron-modified biochar. Environ. Sci. Pollut. Res. 25, 2079220801. https://doi.org/10.1007/s11356-018-2268-8

Yang, F., Zhang, S., Li, H., Li, S., Cheng, K., Li, J.-S., Tsang, D.C.W., 2018a. Corn straw-derived biochar impregnated with alpha-FeOOH nanorods for highly effective copper removal. Chem. Eng. J. 348, 191-201. https://doi.org/10.1016/j.cej.2018.04.161

Yang, F., Zhang, S., Sun, Y., Cheng, K., Li, J., Tsang, D.C.W., 2018b. Fabrication and characterization of hydrophilic corn stalk biochar-supported nanoscale zero-valent iron composites for efficient metal removal. Bioresour. Technol. 265, 490-497. https://doi.org/10.1016/j.biortech.2018.06.029

Zhang, N., Fang, Z., Zhang, R., 2017. Comparison of Several Amendments for In-Site Remediating Chromium-Contaminated Farmland Soil. Water. Air. Soil Pollut. 228. https://doi.org/10.1007/s11270-017-3571-6

Zhang, R., Zhang, N., Fang, Z., 2018. In situ remediation of hexavalent chromium contaminated soil by CMC-stabilized nanoscale zero-valent iron composited with biochar. WATER Sci. Technol. 77, 1622-1631. https://doi.org/10.2166/wst.2018.039

Zhou, Y., Gao, B., Zimmerman, A.R., Chen, H., Zhang, M., Cao, X., 2014. Biochar-supported zerovalent iron for removal of various contaminants from aqueous solutions. Bioresour. Technol. 152, 538-542. https://doi.org/10.1016/j.biortech.2013.11.021

Zhou, Y.-F., Haynes, R.J., 2010. Sorption of Heavy Metals by Inorganic and Organic Components of Solid Wastes: Significance to Use of Wastes as Low-Cost Adsorbents and Immobilizing 
Agents. Crit. Rev. Environ. Sci. Technol. 40, 909-977.

https://doi.org/10.1080/10643380802586857

Zhu, S., Huang, X., Wang, D., Wang, L., Ma, F., 2018. Enhanced hexavalent chromium removal performance and stabilization by magnetic iron nanoparticles assisted biochar in aqueous solution: Mechanisms and application potential. Chemosphere 207, 50-59. https://doi.org/10.1016/j.chemosphere.2018.05.046 
615 Figure 1. Total water-extractable arsenic ( $\left(\mathrm{s}_{\text {water }}\right)$, copper $\left(\mathrm{Cu}_{\text {water }}\right)$ and chromium $\left(\mathrm{Cr}_{\text {water }}\right)$ after 56 days 616 of incubation, measured with ICP-OES ( $n=4$ except for control, $n=6$ ). Error bars represent standard 617 deviations; different letters indicate statistically significant differences between treatments at $p<0.05$. $618 \mathrm{BC}=$ biochar; "coarse" and "fine" refer to different particle sizes of the biochar; $Z \mathrm{VI}=$ zero-valent iron.

619 Figure 2. (A) Bioavailable copper ( $\mathrm{Cu}_{\text {bio }}$ ) measured by $\mathrm{Cu}$ biosensor analysis with Pseudomonas fluorescens DF57 Cu15 ( $n=4$ except for control, $n=6$ ). Error bars represent standard deviations; different letters indicate statistically significant differences between the treatments $(p<0.05)$. BC $=$ biochar; "coarse" and "fine" refer to different particle sizes of the biochar; ZVI = zero-valent iron. (B) Comparison of bioavailable copper $\left(\mathrm{Cu}_{\text {bio }}\right)$ and total water-extractable copper $\left(\mathrm{Cu}_{\text {water }}\right)$ after 56 days of 624 incubation. ( $n=4$ except for control, $n=6$ ). Error bars represent standard deviation; different letters 625 indicate statistically significant differences between the treatments $(p<0.05)$; statistical analysis was 626 performed separately for $\mathrm{Cu}_{\text {water }}$ and $\mathrm{Cu}_{\text {bio, }}$ meaning that different letters cannot be used for 627 comparison between $\mathrm{Cu}_{\text {water }}$ and $\left.\mathrm{Cu}_{\text {bio }}\right) . \mathrm{BC}=$ biochar; "coarse" and "fine" refer to different particle sizes of the biochar; $\mathrm{ZVI}=$ zero-valent iron.

Figure 3. $\left[{ }^{3} \mathrm{H}\right]$ leucine incorporation, normalized by the mean of the control at Day 1 ( $n=4$ for noncontrol treatments; $n=6$ for control treatment except for control at Day $7, n=5$ ). Error bars represent

631 standard deviations; different letters indicate statistically significant differences between treatments 632 within one sampling time at $\mathrm{p}<0.05 . \mathrm{BC}=$ biochar; "coarse" and "fine" refer to different particle sizes 633 of the biochar; $\mathrm{ZVI}=$ zero-valent iron. 


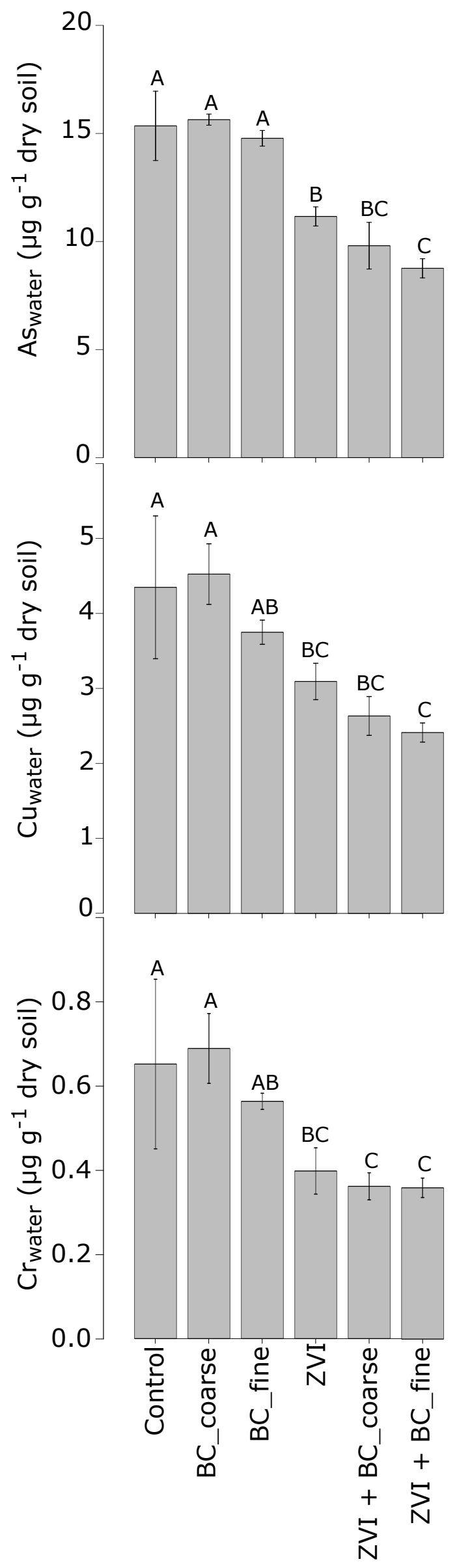




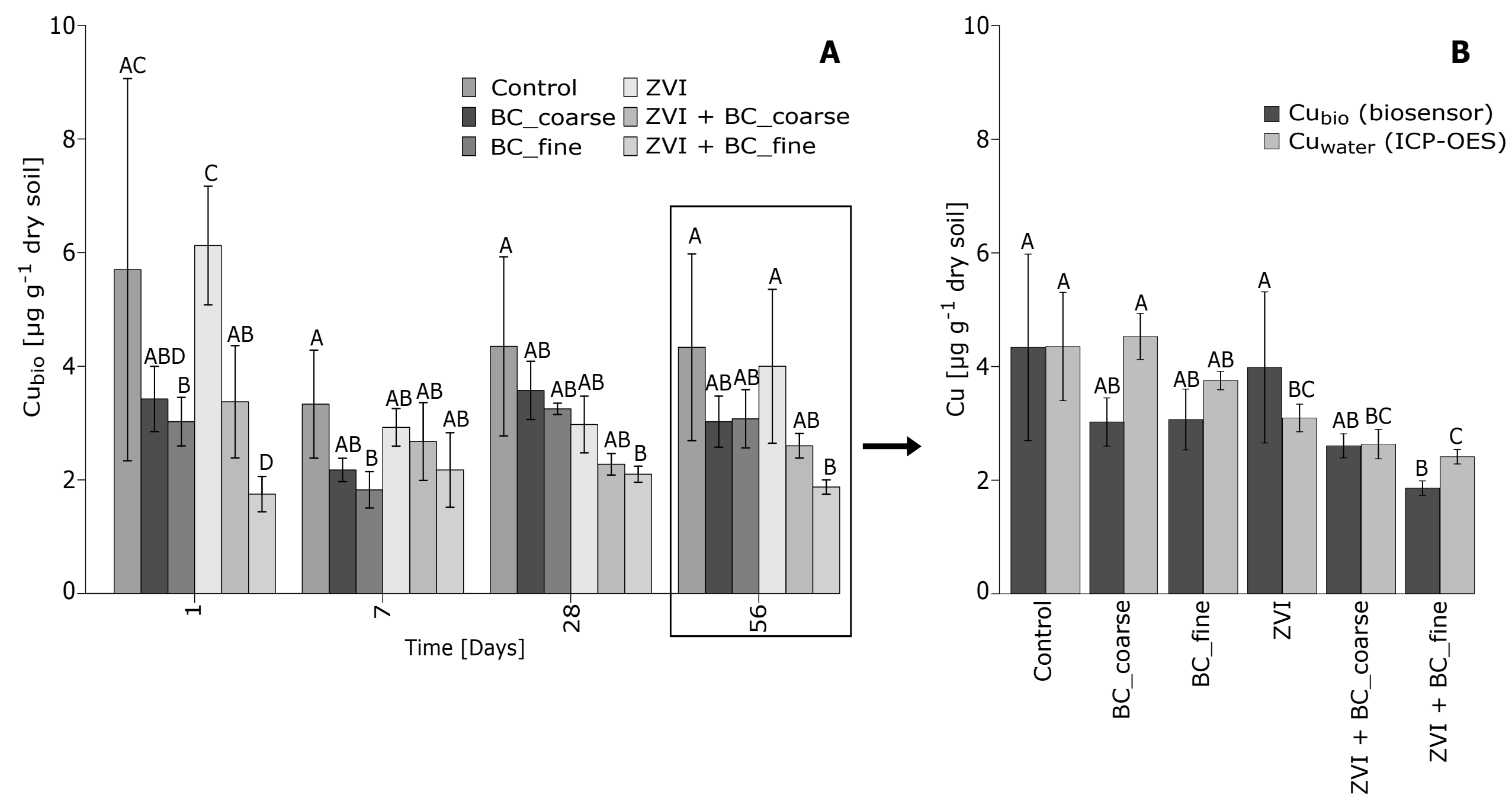




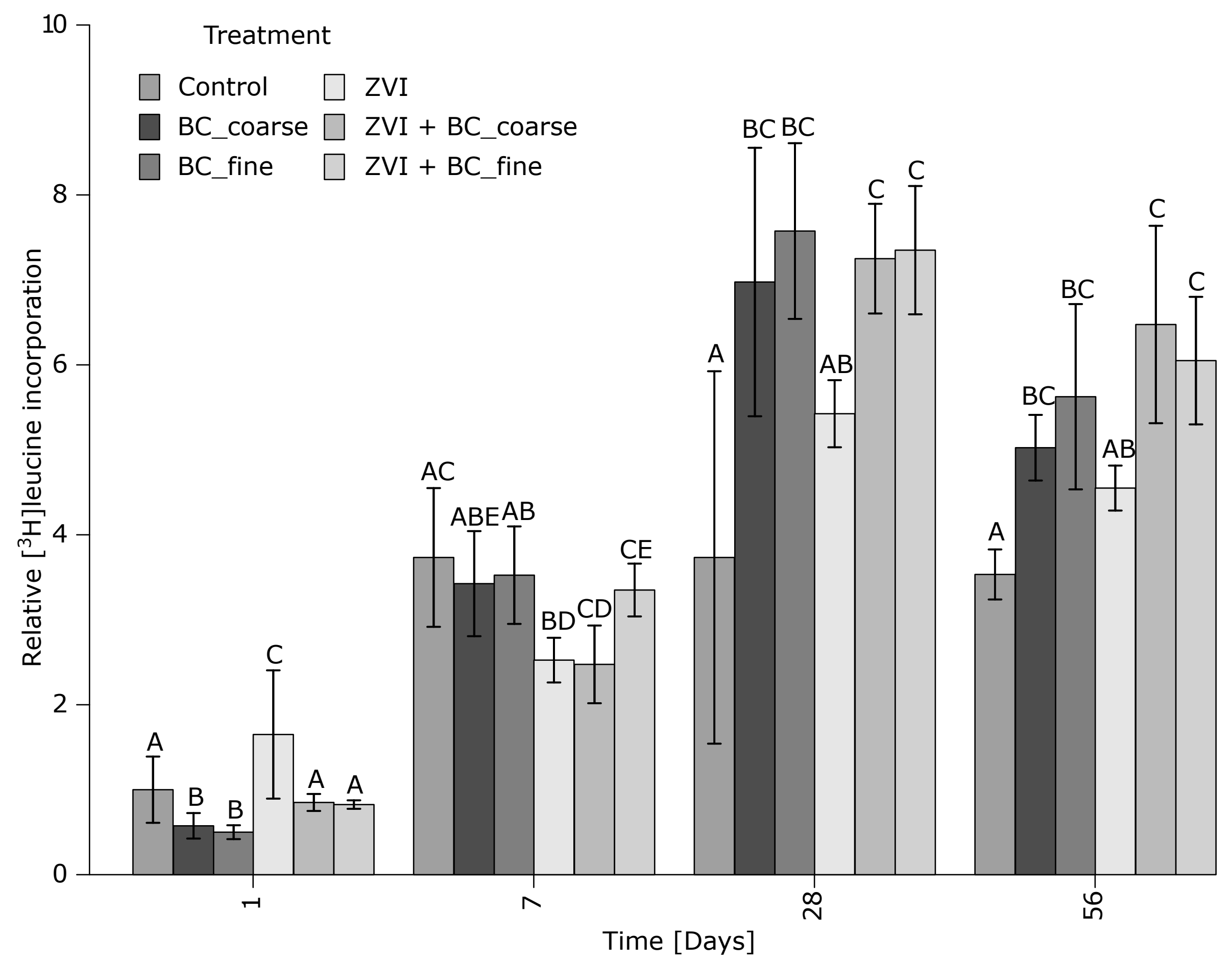


Table 1: Soil and biochar characteristics.

\begin{tabular}{|c|c|c|c|c|c|c|c|c|c|c|}
\hline & $\bar{C}$ org & $\mathrm{N}_{\mathrm{t}}$ & $\mathrm{pH}\left[\mathrm{H}_{2} \mathrm{O}\right]$ & $\overline{A l}$ & As & $\mathrm{Cr}$ & $\mathrm{Cu}$ & $\mathrm{Fe}$ & $\mathrm{Pb}$ & $\mathrm{Zn}$ \\
\hline & $\%$ & $\%$ & & & & & {$\left[\mu \mathrm{g} \mathrm{g}^{-1}\right]$} & & & \\
\hline Soil & 2.3 & $<\angle O D$ & 6.4 & 7974 & 1364 & 540 & 1662 & 10580 & 29 & 120 \\
\hline Biochar & 77.44 & 0.58 & 10.1 & 911 & 9 & 8 & 50 & 993 & 5 & 69 \\
\hline
\end{tabular}


Table 2: Treatment effect on water-extractable elements after 56 days of incubation. ( $n=4$ except for control, $n=6)$. Results are presented as means \pm std. Different letters indicate statistically significant differences at $p<0.05) . B C=$ biochar; "coarse" and "fine" refer to different particle sizes of the biochar; $\mathrm{ZVI}=$ zero-valent iron

\begin{tabular}{lcccccc}
\hline$\left[\mu \mathrm{g} \mathrm{g}^{-1}\right]$ & Control & $\mathrm{BC}_{\text {coarse }}$ & $\mathrm{BC}_{\text {fine }}$ & $\mathrm{ZVI}$ & $\mathrm{ZVI}+\mathrm{BC} C_{\text {coarse }}$ & $\mathrm{ZVI}+\mathrm{BC}$ fine \\
\hline $\mathrm{Al}$ & $88.27 \pm 7.16^{\mathrm{A}}$ & $67.49 \pm 3.86^{\mathrm{BC}}$ & $59.34 \pm 2.69^{\mathrm{BD}}$ & $75.07 \pm 2.16^{\mathrm{C}}$ & $51.45 \pm 3.82^{\mathrm{DE}}$ & $46.94 \pm 1.19^{\mathrm{E}}$ \\
$\mathrm{Ca}$ & $21.16 \pm 0.91^{\mathrm{A}}$ & $18.83 \pm 0.44^{\mathrm{B}}$ & $19.11 \pm 0.15^{\mathrm{B}}$ & $20.58 \pm 0.18^{\mathrm{A}}$ & $18.07 \pm 0.36^{\mathrm{B}}$ & $18.21 \pm 0.33^{\mathrm{B}}$ \\
$\mathrm{Cr}$ & $0.65 \pm 0.20^{\mathrm{A}}$ & $0.69 \pm 0.08^{\mathrm{A}}$ & $0.56 \pm 0.02^{\mathrm{AB}}$ & $0.40 \pm 0.05^{\mathrm{BC}}$ & $0.36 \pm 0.03^{\mathrm{C}}$ & $0.36 \pm 0.02^{\mathrm{C}}$ \\
$\mathrm{Fe}$ & $19.93 \pm 6.16^{\mathrm{AB}}$ & $24.63 \pm 2.38^{\mathrm{A}}$ & $21.38 \pm 1.76^{\mathrm{A}}$ & $13.22 \pm 0.98^{\mathrm{B}}$ & $13.90 \pm 0.92^{\mathrm{B}}$ & $13.60 \pm 0.85^{\mathrm{B}}$ \\
$\mathrm{K}$ & $51.10 \pm 1.88^{\mathrm{A}}$ & $121.50 \pm 2.26^{\mathrm{B}}$ & $123.88 \pm 3.11^{\mathrm{B}}$ & $47.51 \pm 0.86^{\mathrm{A}}$ & $108.79 \pm 1.67^{\mathrm{C}}$ & $112.34 \pm 3.12^{\mathrm{C}}$ \\
$\mathrm{Mg}$ & $4.98 \pm 0.89^{\mathrm{A}}$ & $5.74 \pm 0.39^{\mathrm{A}}$ & $5.41 \pm 0.21^{\mathrm{A}}$ & $3.97 \pm 0.16^{\mathrm{B}}$ & $4.09 \pm 0.12^{\mathrm{B}}$ & $4.14 \pm 0.09^{\mathrm{B}}$ \\
$\mathrm{P}$ & $0.90 \pm 0.17^{\mathrm{A}}$ & $1.39 \pm 0.21^{\mathrm{B}}$ & $1.43 \pm 0.07^{\mathrm{B}}$ & $0.62 \pm 0.07^{\mathrm{A}}$ & $0.86 \pm 0.16^{\mathrm{A}}$ & $0.75 \pm 0.14^{\mathrm{A}}$ \\
$\mathrm{Zn}$ & $0.49 \pm 0.05^{\mathrm{A}}$ & $0.37 \pm 0.03^{\mathrm{BC}}$ & $0.31 \pm 0.01^{\mathrm{B}}$ & $0.40 \pm 0.01^{\mathrm{C}}$ & $0.25 \pm 0.02^{\mathrm{D}}$ & $0.23 \pm 0.01^{\mathrm{D}}$ \\
\hline
\end{tabular}


Supporting information for

\section{Assessment of biochar and zero-valent iron for in-situ remediation of chromated copper arsenate contaminated soil}

Hanna Frick ${ }^{a, b, c}$, Stacie Tardifa, Ellen Kandeler ${ }^{b}$, Peter E. Holmª, Kristian K. Brandta*

a Department of Plant and Environmental Sciences, University of Copenhagen, Thorvaldsensvej 40,DK-1871 Frederiksberg C, Denmark, kkb@plen.ku.dk

b Institute of Soil Science and Land Evaluation, Soil Biology Department, University of Hohenheim, Emil-Wolff-Str. 27, 70599 Stuttgart, Germany

' Department of Soil Science, Research Institute of Organic Agriculture FiBL, Ackerstrasse 113, 5070 Frick, Switzerland

${ }^{*}$ Corresponding author

A. MOPS-buffered minimal medium for Cu-Biosensor analysis

After harvesting the overnight culture of the Cu-biosensors, the cells were re-suspended in autoclaved MOPS-buffered minimal medium. Resuspension only took place immediately before addition to the microtiter plate. The medium consists of the following:

- $100 \mathrm{mM} \mathrm{KCL}$

- 20 mM MOPS (pH 7.2 buffer)

- $7.6 \mathrm{mM}\left(\mathrm{NH}_{4}\right)_{2} \mathrm{SO}_{4}$

- $4 \mathrm{mM}$ glycerophosphate

$\rightarrow \mathrm{pH}$ adjustment to 7.2 was performed with $\mathrm{NaOH}$

$\rightarrow$ after autoclaving (at the day of use), glucose was added to a final concentration of $0.8 \%\left(\mathrm{w} \mathrm{v}^{-1}\right)$ 


\section{B. Bioassay}

E. coli bioreporter cells from both pJAMA arsR as well as pUCD 607 HB101 were revived from cryo stocks on LB agar plates with $50 \mu \mathrm{g} \mathrm{L}^{-1}$ ampicillin incubated overnight at $37^{\circ} \mathrm{C}$. One single colony was transferred to $25 \mathrm{ml} \mathrm{LB}+50 \mu \mathrm{g} \mathrm{L}-1$ ampicillin and grown overnight at $37^{\circ} \mathrm{C}$ at $200 \mathrm{rpm}$ in a horizontally positioned in $50 \mathrm{~mL}$ Falcon tubes. Bioreporter cells in the overnight cultures were harvested at $5000 \mathrm{~g}$ for 10 minutes and re-suspended in $L B$ to a final $O_{600}$ of 0.02 . Bioreporter cell suspension $(100 \mu \mathrm{L})$ was subsequently mixed with $100 \mu \mathrm{L}$ of As standard solution or sample solution in white 96-well microtiter plates (NUNCTM , ThermoFisher Scientific Inc., Massachusetts, USA) and incubated for 2 hours at $28^{\circ} \mathrm{C}$. As standards were prepared with both $\mathrm{As}(\mathrm{V})\left(\mathrm{Na}_{2} \mathrm{HAsO}_{4} \times 7 \mathrm{H}_{2} \mathrm{O}, \mathrm{O}-40 \mu \mathrm{M}\right.$ range) and $\mathrm{As}$ (III) ( $\mathrm{NaAsO}_{2}$, $0-4 \mu \mathrm{M}$ range) on each microtiter plate. Finally, $\mathrm{As}(\mathrm{V})$ standard calibration data was used to calculate As bio, justified by results of As redox speciation analysis revealing that on average less than $2.1 \%$ of the total As concentration in the extracts occurred as As(III) (see supporting information SI C and Figure S 2 for both As speciation procedure and results).

\section{Arsenic speciation analysis}

Arsenic speciation was performed using disposable selective cartridges (MetalSoft Center, NY, USA) which retain arsenate (As-V) while arsenite (As-III) passes through. Water extracts were diluted 10 times in order to not exceed the capacity of the cartridges and passed through the cartridge with a syringe at a speed of $60 \pm 30 \mathrm{~mL}$ per minute, whereby the first $5 \mathrm{~mL}$ were discarded (Krogsriis, 2006; Meng et al., 2001). The following $3 \mathrm{~mL}$ of filtrate were collected and acidified with nitric acid $(0.2 \%$ final acid concentration) and stored at $4{ }^{\circ} \mathrm{C}$ until subsequent analysis on graphite-furnace atomic absorption spectroscopy (GF-AAS, PinAAcle $900 Z$ Atomic Absorption Spectrometer, PerkinElmer, Waltham, Massachusetts, USA). Separation of the species by the cartridge was performed as soon as possible after extraction, at least within 5 hours. Results were compared with results for Asext, giving the total As concentration before the cartridge. 


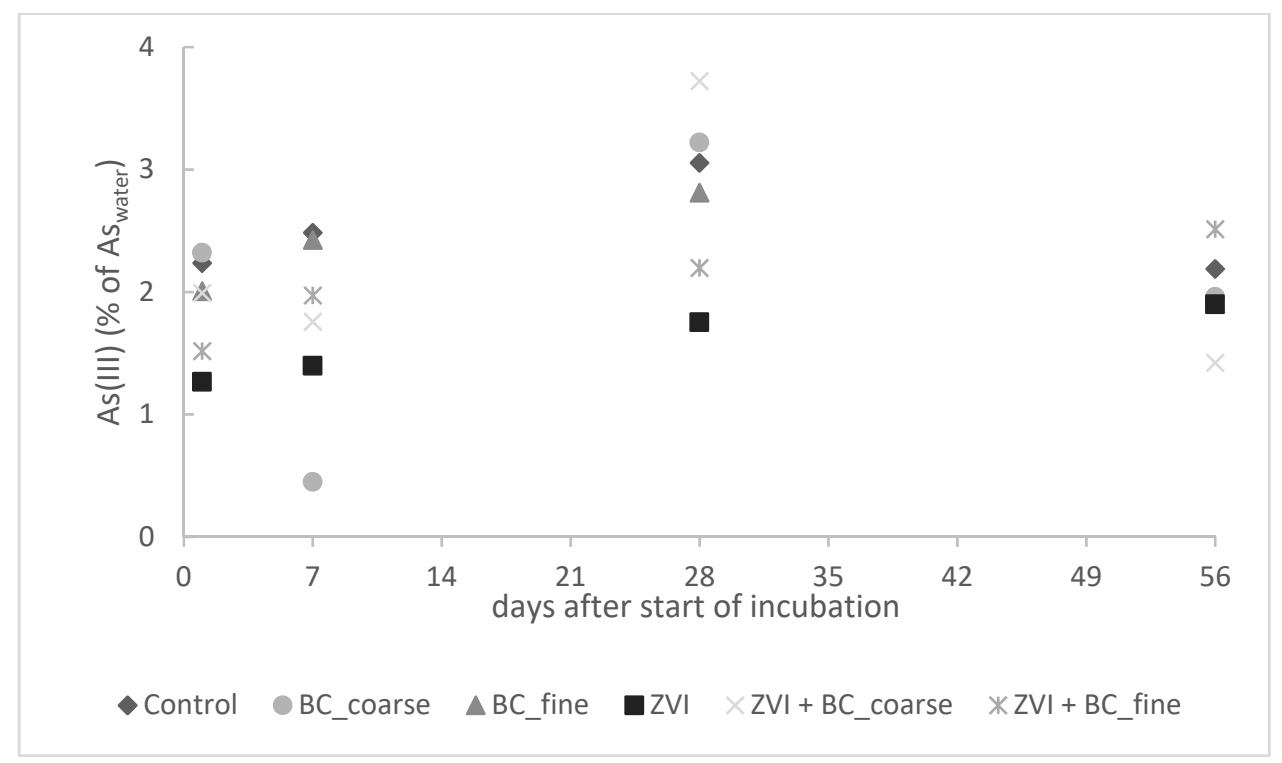

Figure S1: Arsenite (As(III)) content [\%] relative to water-extractable arsenic (As ext) (GF-AAS).

Measurements were taken before and after passage through a selective speciation cartridge. $(n=4$, for control $n=6)$. ( $B C=$ biochar; "coarse" and "fine" refer to different particle sizes of the biochar; $Z \mathrm{VI}=$ zero-valent iron) 


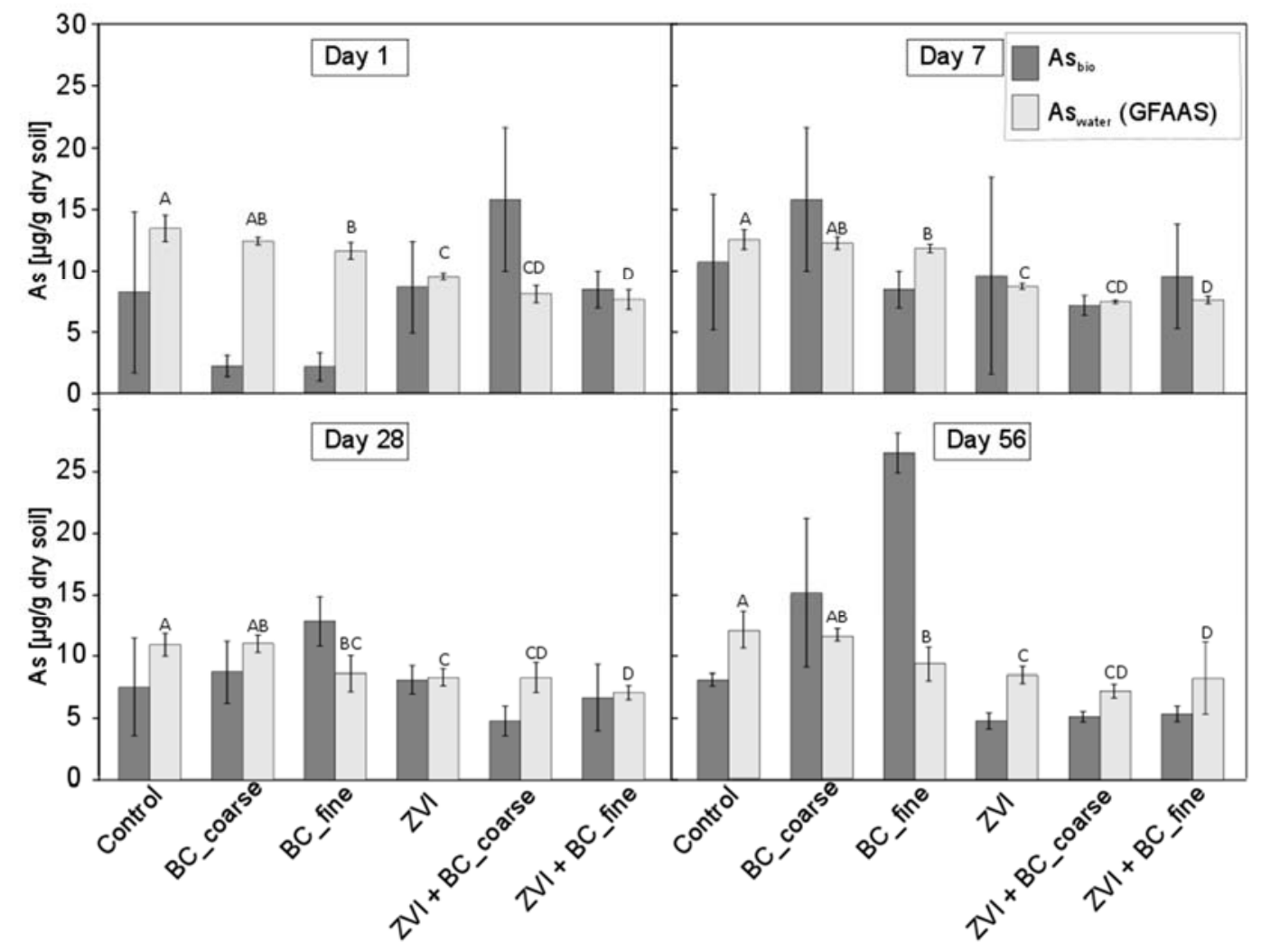

Figure S2: Comparison of $A s_{\text {bio }}$ and $A s_{\text {ext }}$ (measured with GF-AAS) at the different sampling times. ( $n=4$, for control $n=6$; error bars represent standard deviation; different letters indicate statistically significant differences between the treatments $(p<0.05)$; statistical analysis was performed separately for $A s_{\text {ext }}$ and $A s_{\text {bio, }}$, meaning that different letters cannot be used for comparison between $A s_{\text {ext }}$ and $\left.A s_{b i o}\right)$. ( $B C=$ biochar; "coarse" and "fine" refer to different particle sizes of the biochar; ZVI = zero-valent iron) 


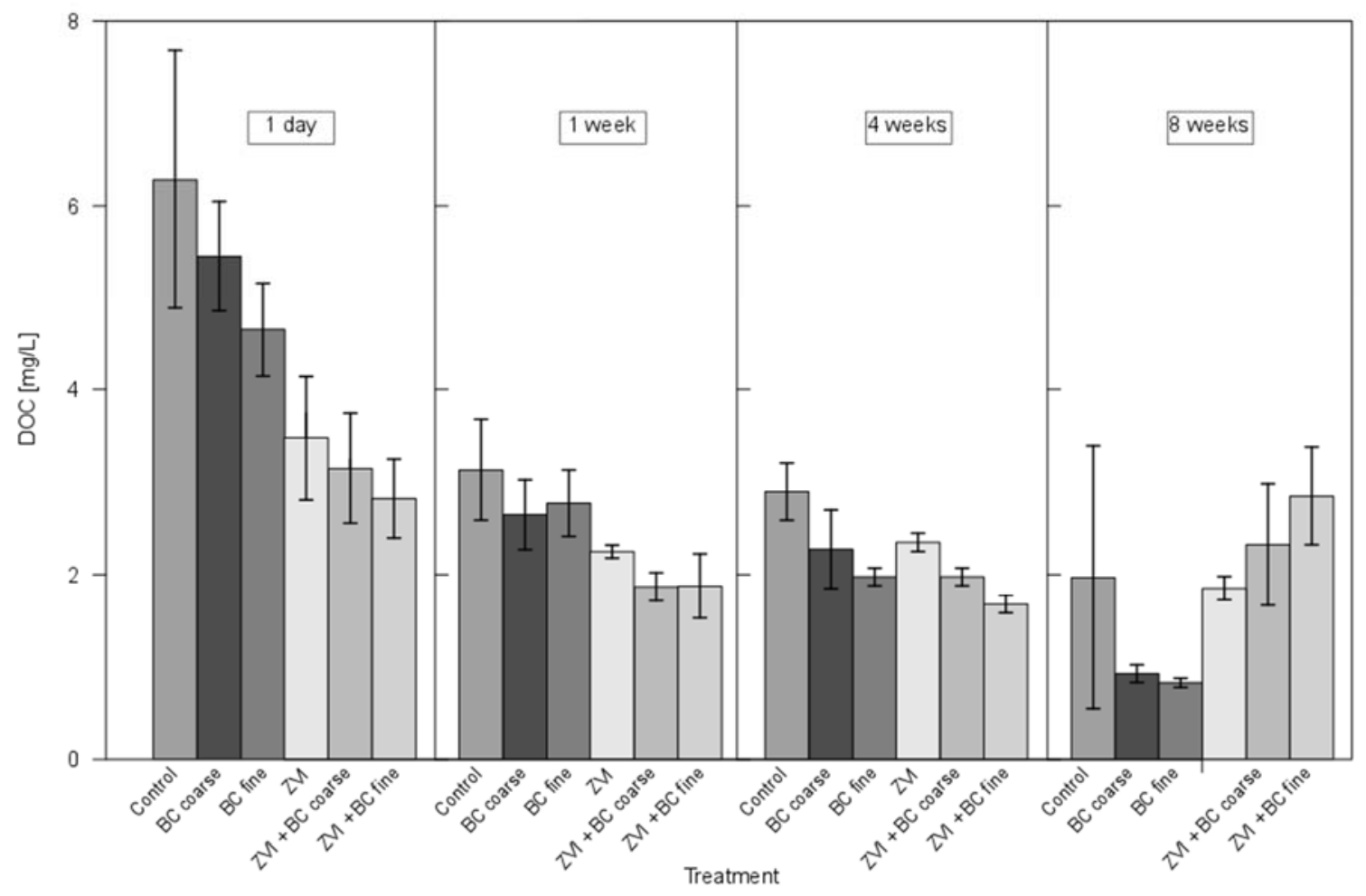

Figure S3: Dissolved organic carbon (DOC) in the water extracts $(n=4$, for control $n=6$, except ZVI $(n=2)$ and $Z V I+B C$ coarse $(n=3)$ at sampling time 1; error bars represent standard deviation) (BC = biochar; "coarse" and "fine" refer to different particle sizes of the biochar; ZVI = zero-valent iron). 


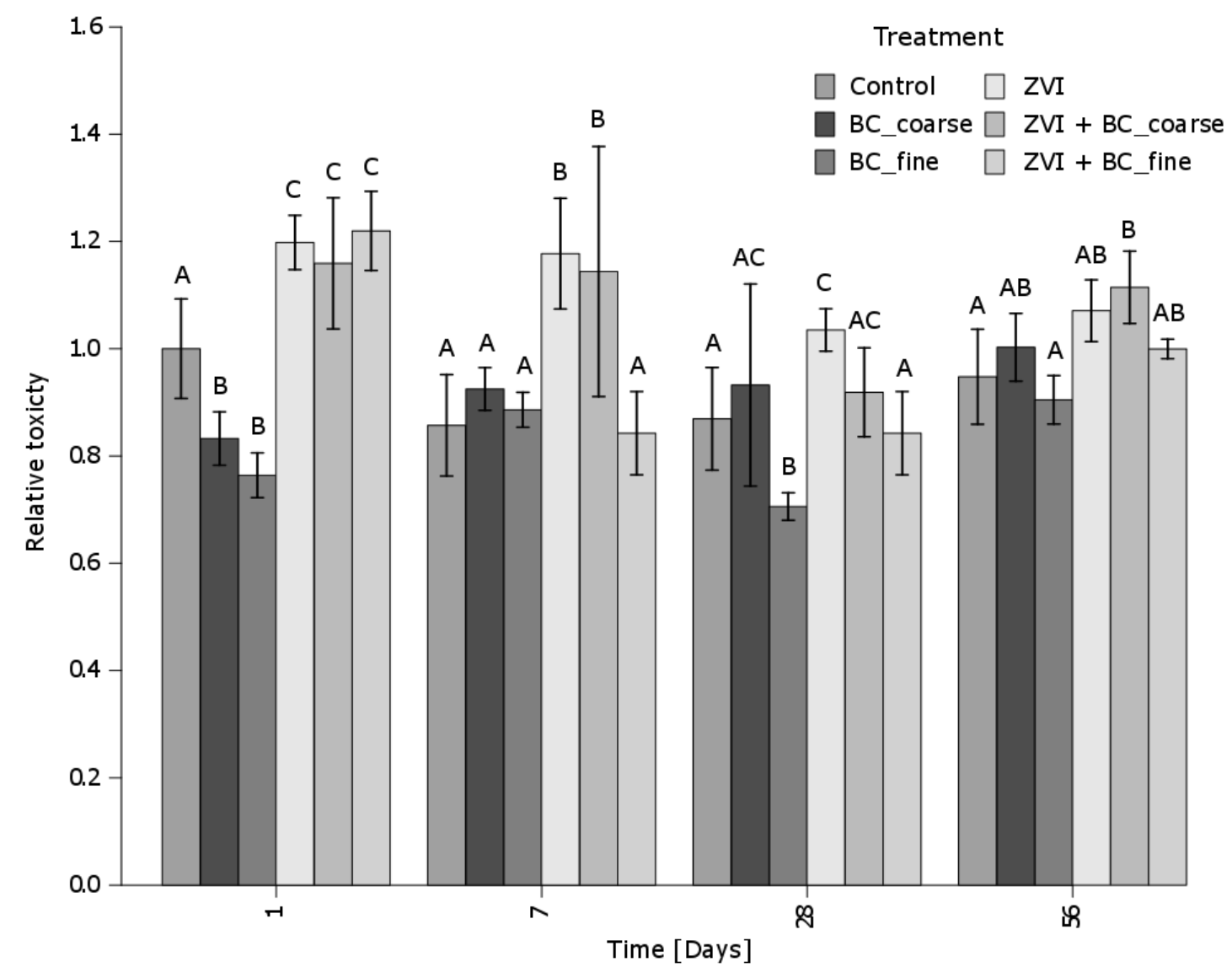

Figure S4: Relative toxicity, measured as bioluminescence from whole-cell bioreporter analysis with E.coli pUCD 607 HB101. Values are normalized by the mean of the control treatment at Day 1 with higher values indicating reduced toxicity $(n=4$, for control $n=6$; error bars represent standard deviation; different letters indicate statistically significant differences between treatments within one sampling time at $p<$ 0.05). (BC = biochar; "coarse" and "fine" refer to different particle sizes of the biochar; ZVI = zero-valent iron) 